\title{
Career Development in Children (Childhood): Literature Review
}

\author{
Heppi Sasmita ${ }^{1^{*}}$, A Muri Yusuf ${ }^{2}$, Mega Iswari ${ }^{3}$, Afdal $^{4}$ \\ ${ }^{1}$ Poltekkes Kemenkes Padang, Indonesia, ${ }^{234}$ Universitas Negeri Padang, Indonesia \\ *Corresponding author, e-mail: heppisasmita@yahoo.com
}

Received May 30, 2021; Revised May 31, 2021; Accepted June 02, 2021; Published Online 2021-06-03

\section{Conflict of Interest} Disclosures:

The authors declare that they have no significant competing financial, professional or personal interests that might have influenced the performance or presentation of the work described in this manuscript

\begin{abstract}
Career development is one of the long developments in the life span experienced by individuals that lead to self-actualization as the pinnacle of successful career development. Career involves the stages of individual development in achieving and completing from one stage to the next. The success of completing developmental tasks from existing developmental stages determines the individual's success in fulfilling developmental tasks at higher stages. Therefore, career guidance is very much needed in childhood so that the career path is more focused and, in this case, of course, the counseling guidance teacher plays an important role in directing and mentoring students who are in such an educational institution.
\end{abstract}

Keywords: Career Development, Childhood, Literature Review

\section{Introduction}

Guidance and counseling are services provided to students in educational institutions both individually and in groups, in order to be able to independently and develop optimally in the fields of personal guidance, social guidance, tutoring and career guidance, through various types of services and supporting activities. , based on the prevailing norms.

In general, the objectives of this guidance and counseling service are in accordance with the objectives of national education, as stipulated in the National Education System Law No. 20 of 2003, namely to develop the potential of students to become human beings who believe and fear God Almighty, have a noble character, are healthy, knowledgeable, capable, creative, independent, and become democratic and responsible citizens. 
While the specific objectives of guidance and counseling services can help students achieve their personal, social, learning and career development goals. This guidance and counseling service is provided by counselors in schools. The counselor has the duties, responsibilities, and authority in the implementation of guidance and counseling services related to the self-development of students according to their needs, potentials, talents, interests, and personalities. With the provision of appropriate and continuous guidance services, students are able to understand their strengths and weaknesses and be independent and able to optimize their potential, talents, and interests.

One of the guidance and counseling services that can be applied in schools is career guidance. Career development in the life span leads to self-actualization as the pinnacle of individual success. Career involves stages of individual development to achieve and complete developmental tasks from one stage to a higher stage. Therefore, career guidance should of course be given to students since elementary school. Gysbers (2005) states that career guidance activities begin in primary schools with an emphasis on developing career awareness, while in secondary schools career guidance activities are directed at developing career awareness, exploration and career planning.

According to Super (in Gothard, 2001), individuals at primary school age are in a growth stage career (career growth) that starts from birth to 14 years. In this range of career development, the career development task that must be fulfilled by individuals is career awareness. Awareness career (career awareness) is a form of career maturity contained in the primary school age children.

Zunker (2006) states that career awareness is a career maturity that needs to be achieved by individuals and needs to be provided at the basic education level. Furthermore, he explained that the emphasis of attention on primary school career development is directed at achieving the overall goal of achieving understanding and awareness (self-awareness of self or self-knowledge), knowledge of various jobs in the world of work (knowledge of the diversity of). the world of work), the relationship between school performance and career choice options, the development of a positive attitude toward work.

The explanation above explains that career planning is one of the most important aspects in individual career development. Skill in making decisions is the main goal in career planning that must be taken so that it can run smoothly and successfully. A person's success can be measured by looking at the success of the career path he has. Success in a career can be felt by feeling proud of getting the job that is expected, more income, high social status and being respected by others. On the other hand, if someone fails to pursue a career, they will feel inferior with the status of unemployment, unable to make ends meet, and being ostracized by society. So that with careful career planning while in a school environment, it can help someone to get to know and understand more about their talents and interests. The existence of career awareness carried out by individuals can step into career exploration, career decision making, and career planning to achieve a job that best fits their potential.

According to Paton \& Mc.Mohan (2001) there are three fundamental issues as a rational for career guidance in elementary schools, namely: 1) career development that all individuals must undergo is a lifelong process in an individual's life. Individual success beyond the task of career development at one age stage determines success at the next stage of development, 2) schools have an influence on children's lives, so it would be better if the influence exerted by schools is intensively enhanced through the career guidance that has been provided. 3) the importance of counseling guidance in elementary schools because the educational stages that individuals go through are rotating ladders that students need to reach to the desired top location, namely a job that is in accordance with the individual.

From the context of research on this, the author via this article explores the career development in childhood (childhood) aims to analyze the system of career development in childhood(childhood)are applied in educational institutions that will affect the outcome of trust and satisfaction of the people who very high towards these educational institutions.

\section{Method}

This research uses a type of library research, namely research where the data is obtained from literature studies or related literature such as books, online journal systems (OJS), google scholar, ebooks and so on. Then analyzed theoretically-philosophically, it is concluded that its relevance and contextualization are raised. The approach used is a phenomenological approach to see how career development in childhood can be done in schools so that the goals of Islamic education are achieved effectively, efficiently and productively. 


\section{Result and Discussion}

\section{Career}

Planning regarding the future in the long term must be planned in advance. According to Super (in Sukardi, 1997) career planning is a series of jobs, positions and positions that lead to life in the world of work. Planning is a process for planning goals to be achieved and how to achieve them. This is of course with careful planning, then someone will be able to determine the steps and ways to achieve this goal.

According to Frank Parson in Winkel \& Hastuti (2010) formulating career planning as a way to help students choose a career field that suits their potential, so that they can succeed in the field of work. Career planning needs to be prepared before students jump directly into the career world. Career planning is based on the potential of students so that there is no conflict between the chosen career and the potential that students have. Meanwhile, Simamora (2011) suggests that career planning is a process where individuals can identify and take steps to achieve career goals. Where in the career planning process individuals will gain knowledge about the potential that exists in students which include skills, interests, knowledge, motivation, and characteristics that are used as a basis in career selection to be able to determine the stages that can be selected.

Based on the above opinion, it explains that career planning is a process of selecting career goals and ways or stages to achieve these career goals based on the potential they have. The chosen career target is the choice of the students themselves. The process of selecting career goals must consider the potential that exists in oneself including the talents, interests, personalities, abilities in students so that they are able to determine career goals, then the methods that must be followed to achieve the chosen career can be determined. Suherman (2009) states that the career planning aspect consists of the following indicators:

a. Study career information. Career information includes all information related to careers. Career information can be obtained from a variety of sources, such as electronic media, print media or direct sources. Students who have career planning will take advantage of the information that has been obtained from various sources to be studied so that they can have an understanding of careers.

b. Talking about careers with adults. Students who have career planning will assume that adults are people who have a lot of experience and knowledge including one of the experiences and knowledge of careers.

c. Attending additional education (courses). Following courses or additional education is expected so that students have skills related to the career that has been selected in career planning. Having the skills needed in a career will make it easier for students to be successful in their planned career.

d. Participate with extracurricular activities. Students who have career planning will take advantage of extracurricular activities in school as a medium to add skills that will be used in career achievement in accordance with the aspirations of each student.

e. Attending training related to the desired job. Following training related to the desired job will add to the existing skills of students and be able to increase knowledge about careers.

f. Knowing the desired working conditions. Students who have career planning will have a high curiosity about the desired work conditions.

g. Know the educational requirements for the desired career. To enter a career, certain conditions are required.

\section{Career Guidance Career}

Guidance according to Super is defined as the process of helping individuals to develop unity and selfimage and their role in the world of work. Based on this super opinion, there are two basic essences contained in this definition, namely: a) the process of helping individuals to understand and accept themselves and $b$ ) the process of helping individuals understand and adapt to the world of work. (Sahril, 2015).

According to Winkel, career guidance is an aid in preparing for the world of work, selecting a specific job field or position (profession) as well as equipping oneself to be ready to assume the position and in adjusting to the demands of the job field that has been entered. Based on the above understanding, career guidance can mean an assistance from the supervisor to the mentor (student) in dealing with and solving career problems. Career guidance is also a type of guidance that helps students face and solve problems related to certain careers. (Tohirin, 2007). 
The role of counseling in schools is very important in providing career guidance services by providing various study programs as preparation for entering the world of work. Another opinion expressed by Walgito (2010) argues that career guidance is an attempt to know and understand oneself, understand what is in oneself well, and to know well what jobs exist and what requirements are required for that job. Students can combine what is demanded by a job or career with the abilities or potentials that exist within the individual. The level of education is also an important aspect as a determining factor in the choice of type of work.

So, career guidance is a program of assistance provided by tutors to students to optimize their potential in preparing for the world of work. One of the preparations is to take the desired career-relevant education level. Therefore, in making these preparations, of course, first steps are needed, including by doing career planning which is one of the goals of career guidance.

Some aspects of career problems that require career guidance services in schools, namely: understanding the world of work, planning and selecting a certain career or position (profession), providing various career-oriented study programs, life values related to career, future aspirations , interest in certain careers, abilities in certain career fields, special talents for certain careers, personality related to certain careers, family expectations, future careers to be obtained, adjustment to the demands contained in a particular career or position (profession), the job market, career development possibilities, and so on. (Tohirin, 2007).

According to Sulistyarini (2014) the field of career guidance contains subject matter, namely: a) early introduction to the world of work and efforts to earn income to meet the needs of life, $b$ ) introduction to general and simple career orientation and information, c) introduction and self-understanding Initially related to the career trend to be developed, d) orientation and simple information towards higher education, especially related to the career that is about to be developed.

\section{Career Development in the Childhood}

According to Donald Super about career development that is very broad in scope, because the development of the position is seen as a process that includes many factors. These factors can be seen from the individuals themselves and the environment that interact with each other and together form a person's career development process. The choice of position is a combination of various factors in the individual itself such as needs, personality traits, and intellectual abilities, and there are also factors outside the individual, such as social, economic, and family standards of life, variations in the demands of the cultural environment and opportunities or opportunities that arise. . The emphasis of this lies in the factors of the individual himself. (Rahmad, 2013).

The theory of career self-concept (Career Self Concept Theory) was put forward by Donald Super which states that the individual self-concept plays an important role in one's career choice. Super believes that adolescence is when someone builds a self-concept about a career, career development consists of five different phases, namely:

a. Crystallization phase aged 14-18 years. Adolescents build a picture of work that is still mixed with their existing self-concept in general.

b. Age specification phase 18-22 years. They narrow down their career options and start directing their behavior so that they can work in a particular career area.

c. Implementation phase aged 21-24 years young adults' complete school or training and enter the world of work.

d. Stabilization phase aged 25-35 years. Making career-specific decisions.

e. Consolidation phase aged 35 years and over. A person will advance their career and will reach a higher position.

This age grouping is an estimate and not an absolute one. During the period of school career development, it has an influence on children's lives, so it would be better if the influence exerted by the school was intensively increased through the career guidance that has been provided. Finally, school is an individual's first step towards education, training and employment. The need for career guidance in primary schools is increasingly important and essential when it is related to what is learned or what children fail to learn about life, life, and the search for happiness.

According to Ginzberg, the career selection process is not only occasional but experiences a development process that includes a period of time. In general, it covers a period of six to ten years, starting from around 11 years of age and ending after 17 years of age or early adulthood. There are three 
periods or stages in the job selection process, namely fantasy, tentative, and realistic following characteristics:

Table 01. Development Process

\begin{tabular}{lll}
\hline Periods & Age & Characteristics of \\
Fantasy & $\begin{array}{l}\text { Childhood (before age } \\
11 \text { years) }\end{array}$ & $\begin{array}{l}\text { In this early-stage work orientation appears in pure play. Towards } \\
\text { the end of this stage the game becomes job orientation. }\end{array}$ \\
Tentative & $\begin{array}{l}\text { Early adolescence (ages } \\
11-17 \text { years old }\end{array}$ & $\begin{array}{l}\text { A transition process characterized by gradual recognition of job } \\
\text { requirements. Introduction to perspectives of talents, interests, } \\
\text { abilities, skills, employee benefits, values and time. }\end{array}$ \\
Realistic & $\begin{array}{l}\text { Mid-adolescence (ages } \\
17 \text { to 17) early } \\
\text { adulthood) }\end{array}$ & $\begin{array}{l}\text { Integration of abilities and interests Continued development of } \\
\text { values Specifications of occupational choices and crystallization of } \\
\text { occupational patterns }\end{array}$ \\
\hline
\end{tabular}

(Source: Juliana, 2013)

The Explanation of the table above is described as follows:

1. Fantasy

Period This period lasts for individuals from childhood to approximately 10 years or 11 years (elementary school period). At this time, the job selection process is still arbitrary or random, without being based on careful consideration (rational and objective) regarding the existing reality. The choice of work at this time was only based on the impression that could give birth to pleasure, and it was obtained from the people who worked or line work environment.

According to Winkel (2005) during this period, children only play at first and this game is considered to have nothing to do with the world of work. Therefore, this phase has not been given much attention by Ginzberg's group. At the end of this first phase, the child's play begins to show some indications that in the future he will tend to choose a certain number of activities that lead to the role of a holder of a position.

2. Tentative

Period This period takes place at the age of approximately 11 years to 17 years or when the children attend junior and senior high school. At this time, the choice of work has developed According to Ginzberg, this period was classified into four stages, namely:

a. Stage (Interest Interest) at the age of 11-12 years, which is a period where individuals tend to do work or activities only according to their interests and preferences. Career considerations are also based on individual pleasure, interest or interest in career objects, without considering existing factors.

b. Phase capacity (Capacity)at the age of 13-14 years, the time when people started to do work or activities are based on its ability in accordance with the aspirations of the job. The orientation of job choice at this time was in the form of an effort to match one's abilities with their interests and preferences.

c. Phase value (Value)at the age of 15-16 years, which is the stage where people begin to realize that there is a content of the specific values of any type of work, whether the content of a personal nature value or set of values that are kemasyarakatan. At this stage, a clearer perception of the occupational style begins to form.

d. The transition stage (Transition) at the age of 16-17 years, which is a condition in which individuals will integrate their previous preferred orientation (interests, capacities, and values) to be realized in their lives. This stage is also known as the stage of gradual introduction to job requirements, recognition of interests, abilities, employee benefits, values, and time perspectives. The decision that becomes the choice is already a form of responsibility and a consequence of the chosen career pattern. 
3. Realistic

Period This period takes place at the age of 17-24 years or during college or starting work. During this period, occupation of work has experienced a more realistic development. The orientation of interests, capacities, and values that individuals have towards work will be reflected and integrated in a coherent and structured manner in a vocational frame (crystallization of occupational patterns) to select the type of work and / or select universities according to their tentative direction (specifications). This period was divided into three stages, namely:

a. Exploration stage (exploration). At this stage the individual narrows down the possibility of career choices by providing an assessment of work-related experiences or activities in relation to actual job demands. This assessment essentially serves as a reference and or condition to be able to enter the job market or to continue education to higher education.

b. Phase crystallization(chrystalization). At this stage, the individual's assessment of experiences or activities related to work, whether successful or unsuccessful, will coagulate in the form of clear vocational patterns, so that individuals have a commitment to specific careers and feel more secure when they hold certain positions.

c. The specification stage (specification). This stage is the stage of specific or specific job choices. At this stage, all segments in career orientation, starting from interest, capacity, and value orientation, to the exploration and crystallization stage have been considered (compromise) in a mature manner (determination of optimal developmental tasks) in choosing the direction and career goals in the future. .

Several activities in elementary schools have provided career guidance for students. There are many activities in schools such as entrepreneurship day or selling day. This activity is a way for schools to guide students to accommodate their future career development needs. Career guidance developed during childhood can be integrated into learning.

Childhood is the initial period of vocational development which involves aspects of the development, transition and change tasks. At that time, according to Hartung, Porfeli and Vondracek, in the research of Yulia Ayriza et al (2015), stated that children must reach the basis of career adaptability to achieve the future, make educational and vocational decisions, explore self and occupation, and solve problems. Regarding childhood, it is necessary to introduce career awareness for children at the Kindergarten or Elementary School level. This discussion is actually a big challenge for the nation's educators, especially practitioners who are involved in the education of Kindergarten and Elementary School children. (Aditya, 2017). Based on this description, it can be understood that if students succeed in understanding about careers since elementary school, then this will support the success of their career in the future and will support the success of their development in other fields and in the following period.

According to the National Guidance Association (1930) in Wijaya (1994), career guidance is a process of providing assistance or information services, experiences and advice to individuals to choose, prepare, adapt and establish themselves in a job. (Dudi, 2021). Guidance and counseling teachers (counselors) in providing career guidance services to students in the form of information about further education and job planning, according to the interests and abilities of students, providing advice or solving problems about obstacles that may be experienced, and understanding themselves and values planning for the future.

Knight (2015) describes that career development at the primary school level is very important and becomes the foundation for further career development to prepare individuals to pursue careers. One of the recommendations given by Knight is to choose a specific method of providing guidance services. Classical guidance is an effective and efficient method to meet student needs through counseling guidance services.

Knight's opinion above is in accordance with the results of interviews the author conducted from several counseling guidance teachers in schools, they argue that the career development carried out in schools will make it easier for students to determine their future lives. The implementation of career guidance in elementary schools is an effort to help students know themselves and optimize their potential, besides that student are able to identify and be able to learn to make choices and decide what career paths to take in the future. 


\section{Conclusion}

Career development is seen as a process that includes many factors. These factors will affect one's career development. The work to be done and the position to be held (vocational self concept) is part of the overall picture of oneself. The Superview has some very relevant implications for career education and career counseling. The superception of self-image and vocational maturity becomes a guide for an education staff when designing career education and career guidance programs, which lead young people to selfunderstanding and information processing about the world of work, in line with certain stages of career development.

\section{References}

Batubar Juliana, (2013). Career Development and Selection According to Ginzberg and Its Implications for Guidance and Counseling, Journal of Counseling and Education, Vol. 1 No. February 1, p. 43-47.

Dani Wijay Aditya, (2017). The Level Of Understanding Career Of Low Grades Elementary School, EJournal of Guidance and Counseling 3rd Edition, 6th Year, p. 239-251.

Elizabeth B. Hurlock, (1996). Developmental Psychology, Jakarta: Erlangga.

Gothard, B., Mignot, P., Offer, M., \& Ruff, M. (2001). Careers Guidance in Context. London: SAGE Publication.

Gunawan Dudi, (2012). Career Development Guidance Model (Study of Development of a Career Development Guidance Model for Deaf Students in SLB-B Bandung), Educational Research Journal, Vol. 13 No. October 2, p. 1-12.

Gysbers, N. C. (2005). Comprehensive School Guidance Programs in The United States: A Carier Profile. International Journal for Educational and Vocational Guidance. 5, 20321.

John W. Santrock, et al, (2011). Child Development, Jakarta: Salemba Humanika.

Knight, J.L. (2015). Preparing Elementary School Counselor to Promote Career Development: Recomendations for School Counselor Education Program. Journal of Career Development. 42 (3), 7585 .

Rahmad, (2013). Career Guidance A Theoretical Study, Pekanbaru: Riau Creative Multimedia.

Sahril Buchori, (2015). Effectiveness of Career Guidance To improve Student Core Work Skills, Journal of Educational Psychology \& Counseling Vol. 1 No. June 1st.

Sukardi, Dewa Ketut. (1997). Career Guidance in Schools. Jakasrta: Balai Pustaka.

Sulistyarini, and Mohammad Jauhar, (2014). Basics of counseling, Jakarta: Prestasi Pusta karya.

Tohirin, (2007). Guidance and Counseling at Schools and Madrasahs, Jakarta: PT Raja Grafindo persada.

Welde, A.M.J., Bernes, K.B., Gunn, T.M., \& Ross, S.A., (2016). Career Education at the Elementary School Level: Student and Intern Teacher Perspective. Journal of Career Development, 43 (5), 426-446.

Zunker. (2006). Career Counseling: A Holistic Approach. New York, NY: Brooks / Cole 
The authors declare that they have no significant competing financial, professional or personal interests that might have influenced the performance or presentation of the work described in this manuscript.

Copyrights Holder: < Sasmita $><2021>$

https://doi.org/10.xxxx/ $\mathrm{xxxxx}$

Open Access Article | CC-BY Creative Commons Attribution 4.0 International License.

Word Count:
First Publication Right: BISMA The Journal of Counseling 